\title{
Cement Dosage Form
}

National Cancer Institute

\section{Source}

National Cancer Institute. Cement Dosage Form. NCI Thesaurus. Code C45414.

A base composed of bonding agents interming led with active and/or inert ing redient(s),

which rapidly hardens into a firm mass upon application. 